\author{
James J. Kellaris, Anthony D. Cox, \& Dena Cox
}

\title{
The Effect of Background Music on Ad Processing: A Contingency Explanation
}

Music is an increasingly prominent and expensive feature of broadcast ads, yet its effects on message reception are controversial. The authors propose and test a contingency that may help resolve this controversy. Experimental results suggest that message reception is influenced by the interplay of two musical properties: attentiongaining value and music-message congruency. Increasing audience attention to music enhances message reception when the music evokes message-congruent (versus incongruent) thoughts.

$\mathbf{M}$ USIC has been a prominent feature in advertising since the first network radio broadcast aired in 1923 (Hettinger 1933). Early broadcasts used signature "theme music" to introduce commercial sponsors. By the late 1930 s, the "singing commercial" had become standard practice. Pepsi's historic "Pepsi-Cola hits the spot" jingle became a jukebox hit in 1941 (Enrico and Kornbluth 1986). Musical ads made a graceful transition to television in the 1950 s, and they continue to play an important role in broadcast advertising today. Estimates of the proportion of TV commercials using music have ranged from about $75 \%$ (Michlin 1984) to over 90\% (Garfield 1988). According to a recent Video Storyboard Tests report, music is used as "the main creative ingredient" in one-third of 500 new TV ads (Tharp 1989).

Advertisers spend large sums of money on the production of musical ads. Creative fees for an original composition can cost over $\$ 10,000$ (Karmen 1989). The rights to popular songs can cost much more (Alsop 1985); for example, Nike paid $\$ 500,000$ for the use of The Beatles' song "Revolution"' (Cocks 1987).

Industry is risking millions of dollars on the belief that music can help ads sell; yet there is no universally accepted explanation of how this works. Some investigators have suggested that music influences listeners mainly through their feelings. For example, Gorn (1982) viewed the effects of ad music from a classical conditioning perspective, suggesting that consumers' feelings toward a piece of music may transfer to a product when the two are paired in an ad. Another explanation is that the power of music operates by creating moods (Alpert and Alpert 1990; Bruner 1990; Gardner 1985) that enhance product evaluations and facilitate message acceptance.

James J. Kellaris is Assistant Professor of Marketing at the College of Business Administration, University of Cincinnati. Anthony D. Cox and Dena Cox are Associate Professors of Marketing, Indiana University School of Business. The authors thank Chris Allen, Ken Bernhardt, and Frank Kardes, as well as the $J M$ editor and reviewers, for their comments on earlier drafts of this manuscript.
Though most of the research literature has focused on emotional responses to ad music, it is also important to consider music's impact on message reception and processing. Creating positive feelings during ad exposure may be desirable but have little impact unless the brand and message are remembered. Therefore, the current research examines ad recall and recognition. Our focus on cognitive aspects of ad performance is justifiable on both theoretical and practical grounds. Remembering information such as brand names and message claims often precedes responses at other levels in the hierarchy of effects. Various measures of memorability are used extensively in the advertising industry to assess ad performance (Stewart, Furse, and Kozak 1983; Wells 1964).

Ad memorability is particularly troublesome in the present media environment (Walker and von Gonten 1989). Given the proliferation of "ad clutter" (Webb and Ray 1979), "zipping"' (Yorke and Kitchen 1985) and "'zapping" (Heeter and Greenberg 1985), and low attention levels for broadcast media in general (Krugman 1988), advertisers face a growing challenge of attracting attention to their messages (Olney, Holbrook, and Batra 1991).

Many have claimed that music increases the memorability of ads (Hecker 1984); however, support is mixed. A recent Wall Street Journal article reported that "advertisers are spending a ton of money on music, [but] it looks like it's backfiring ... in many cases, music tracks actually muddle the commercial message'" (Lipman 1991). Correlational studies have found music to enhance (e.g., Hoyer, Srivastava, and Jacoby 1984), inhibit (e.g., Haley, Richardson, and Baldwin 1984; Sewall and Sarel 1986), or have no effect (e.g., Stewart and Furse 1986) on remembering ads. Experimental studies have also produced inconsistent findings: Messages that are sung have been found to produce lower (e.g., Galizio and Hendrick 1972), higher (e.g., Wallace 1991), or equal (e.g., Macklin 1988) recall relative to spoken messages. Several studies have found recall to vary across different types of music (e.g., Belsham and Harman 1977; Tom 1990), but have uncovered no consistent pattern underlying results. 
We propose to illuminate the controversy surrounding recall effects of music by introducing a contingency variable: music-message congruency. Music-message congruency refers to the congruency of meanings communicated nonverbally by music and verbally by ad copy. Attention-gaining background music is hypothesized to enhance recall of brands and messages when the meanings conveyed by music and message are congruent, and interfere with ad processing when music and message convey dissimilar meanings.

\section{Literature Review and Hypotheses}

Traditionally, advertising research has treated music as a unitary "sonic mass," examining the effects of its presence or likability. However, Bruner (1990) and Kellaris and Kent (1991) have noted that music is multi-dimensional and called for research on the interplay of these dimensions in marketing contexts. We explore two properties of music that can exert an interactive influence on ad processing.

\section{Music's Attention-Gaining Value}

The first musical property that can influence message reception is "attention-gaining value," which refers to the activation or arousal potential of musical sound (Kroeber-Riel 1979). Music's ability to engage a listener's attention can stem from objective traits, such as speed and loudness, or subjective traits, such as surprisingness and interestingness (Berlyne 1974). Slow, soft music should have a low attention-gaining value, whereas fast, loud music can be expected to activate higher levels of attention.

In an advertising context, music may contribute to message reception by attracting and holding attention (Hecker 1984). According to one view, attention-getting music should attract attention to an ad, thereby enhancing message reception. A paradox arises, however, in that listeners sometimes attend to the music so closely that the message is not processed. In these cases, music is a distractor that inhibits message reception and processing. Wakshlag, Reitz, and Zillman (1982) found that music that increased attention to a program inhibited learning from it. Anand and Sternthal (1990) found music to have a distracting effect in a radio advertising context.

As Macklin (1988, p. 225) states, “an individual may attend to the music [and] become so enraptured by [it] that the central message of the advertiser is ignored." She suggests that music is likely to have this distracting effect when it is "extraneous to the main concept or theme"' (p. 227). Whether attention-gaining music enhances or distracts from processing may therefore depend on the consistency of meaning conveyed by the music and verbal message.

\section{Music-Message Congruency}

Numerous sources suggest that purely instrumental music can convey very specific meanings that are widely shared across listeners (e.g., Gurney 1880; Meyer 1956; Watson 1942). An early empirical study by Gundlach (1935, p. 642) concluded that "music can elicit in many auditors a fairly uniform characterization solely through factors resident within the musical structure.' Rigg (1937) found that most listeners $(73 \%)$, regardless of musical training, could interpret accurately the intended meanings of unfamiliar musical compositions. More recently, Holbrook and Bertges (1981) demonstrated that untrained and expert listeners share remarkably similar perceptions of the aesthetic expressiveness of classical music performances.

Music can communicate meanings in two distinct ways. First, musical pieces occasionally convey literal meanings by imitating concrete sounds (e.g., bird calls, traffic noises). Second, music has a special ability to convey images, thoughts, and feelings more abstractly as well. As Gurney wrote $(1880$, p. $349-50)$ :

[T]he power of Music to suggest external objects and events and intellectual conceptions ... may take place in two ways. First, the actual sounds and motion of the music may perceptibly resemble actual sounds and motions of other things.... The second way in which images of external facts may be suggested by Music is by general qualities.... [T] which might suggest a quiet succession of waves has naturally an expression of tranquillity [sic] corresponding to the same idea.

Patterns of repeated notes communicate the idea of water flowing in Schubert's Die Schöne Müllerin, Debussy's La Mer, Respighi's Fountains of Rome, and many other compositions. Similar "flowing motion" patterns reinforce the liquid imagery and "cool, refreshing" idea in beverage commercials. Mozart's overture to "The Marriage of Figaro" evokes more complex meanings-lively, romantic, comic, anticipation (Tovey 1937). Music in commercials often communicates similarly complex meanings (for examples, see Scott 1990).

On the basis of music's ability to convey meanings, we propose a "music-message congruency" construct, which can be defined as the extent to which purely instrumental music evokes meanings (i.e., thoughts, images, feelings) that are congruent with those evoked by ad messages. Previous studies have examined variables that are conceptually related to music-message congruency in that they involve some type of stimulus congruity between peripheral and central ad cues. For example, research on picture-word consistency has found brand recall to be higher when the brand name and picture are integrated into a single illustration (Childers and Houston 1984; Lutz and Lutz 1977). Houston, Childers, and Heckler (1987) found recall of product attribute information to be higher when both picture and words communicate the same information. Unnava and Burnkrant (1991) found picture-word congruency to enhance verbal recall when the picture does not evoke distracting imagery. Heckler and Childers (1992) found the presence of relevant (versus irrelevant) pictorial cues to enhance ad recognition.

MacInnis and Park (1991) manipulated a property they label "music's fit with the main theme of the ad." However, in their study, fit was operationalized by manipulating the relevance of the lyrics of a song to the main theme of the ad-i.e., the congruency between two types of verbal cues (song lyrics and ad copy). Additionally, several psychological studies have explored the impact of consistency of verbal information on recall (e.g., Hastie and Kumar 1979; Srull, Lichtenstein, and Rothbart 1985); however, important differences between these studies and ours will be discussed subsequently. 
Though music-message congruency is similar to pictureword consistency and musical fit, it is distinctive in several respects. Music-message congruency differs from pictureword consistency in that it involves aural rather than visual processing and music often conveys meanings in a connotative or evocative fashion, whereas the stimuli used in studies of visual cues have communicated in a more literal, representational manner. Music-message congruency is distinguished from MacInnis and Park's 'fit' construct in that it involves nonverbal-verbal congruency (instrumental music with message copy) rather than verbal-verbal congruency (song lyrics with message copy).

\section{Hypotheses}

In summary, the impact of increasing the attention-gaining value of background music is expected to interact with music-message congruency in the following way: Increasing audience attention to message-congruent music will reinforce retention of the message because similar content is being communicated through both spoken words and musicevoked thoughts. However, increasing audience attention to music that evokes message-incongruent thoughts will not enhance message retention, and may actually impede it by distracting the audience from processing the content of the spoken message. Hence,

$\mathrm{H}_{1}$ : The impact of increasing the attention-gaining value of music on recall of (a) brand name and (b) message points will be more positive when music-message congruency is high than when music-message congruency is low.

Because recall and recognition reflect how much is learned and remembered from an ad and tend to covary strongly (Singh, Rothschild, and Churchill 1988), we anticipate an analogous interactive effect of music's attention value and congruency on recognition:

$\mathrm{H}_{2}$ : The impact of increasing the attention-gaining value of music on recognition of (a) brand name and (b) message points will be more positive when music-message congruency is high than when music-message congruency is low.

\section{Method}

Music's attention-gaining value and music-message congruency were varied in a $2 \times 2$ factorial between-subjects design with a no-music control group. Dependent variables include recall and recognition of brand name and message points. The procedure involved randomly assigning subjects to treatments, giving them a deceptive cover story, exposing them individually to test ads embedded in a radio program, and having them complete a self-administered questionnaire.

\section{Subjects}

We recruited 231 young adults from upper-level business classes at an urban university to participate in the main experiment. Most of these subjects (more than $80 \%$ ) were employed either full- or part-time. Their ages ranged from 20 to 40 years, and gender was about evenly divided $(55.6 \%$ men, $44.4 \%$ women). Subjects came from a variety of urban and suburban neighborhoods, representing 54 metropolitan ZIP code districts. We believe this relatively young sample to be appropriate because this age group constitutes frequent radio listeners (MRI 1989), and they are frequent targets of musical ads (Aaron 1987; Lipman 1991) and consumers of the products represented in the test ads used in this study.

\section{Stimuli and Pretests}

The stimuli were 30 -second radio ads designed by the authors and professionally recorded. The ads were the product of extensive development and pretesting. We sought two sets of musical selections that differed in attention-gaining value but did not differ in appeal or familiarity. Toward this end, we selected 40 pieces of unfamiliar instrumental music, and asked 110 college students to rate them on attention-gaining value, appeal, and familiarity scales (similar to those reported as manipulation check items in the "Measures" section). We preferred to use unfamiliar music to avoid nonmusical associations and meanings stemming from prior exposures. Subjects were processed in small groups, with each group evaluating only four pieces. On the basis of pretest ratings, we narrowed the field to the set of musical selections listed in Figure 1. Six pieces had high attention value $(\bar{X}=4.0)$, and six had low attention value $(\bar{X}$ $=2.6 ; \mathrm{F}=35.8, p<.001)$. The sets did not differ in average appeal or familiarity. Each set contained two classical selections, two foreign, and two in some other genre (e.g., contemporary). We used music of different genres to increase construct and external validities (Cook and Campbell 1979).

In addition to rating the music, subjects were asked to list their thoughts as they listened. Though the music was instrumental, each piece seemed to evoke specific images that were remarkably similar across listeners. On the basis of the thought listings, we selected products to match the images evoked by the twelve pieces. For example, the fastpaced, dissonant "Concerto for Clarinet and Orchestra" by Corigliano evoked thoughts of excitement and danger and images of a high-speed chase in a James Bond or Indiana Jones type movie. These associations suggested an ad for an adventure film.

We retained nine product categories from this process. The relevance of each product or service category for student subjects was verified in a small scale survey $(n=40)$. Each category was personally relevant to at least $80 \%$ of the sample as verified by self-report.

Next, copy was developed for each product. Each message contained the same basic elements in the same format, mentioned the brand three times, and contained about 100 words. Though we attempted to make the ads as similar as possible in terms of how much information they contained, we tested for balance of informational content. Working from written copy, two judges independently counted the number of thoughts imparted by each ad. The two sets of judgments were positively and significantly correlated ( $r=$ $.40, p<.05)$. We summed and averaged the two sets of judgments and used this as the dependent variable in a variance analysis with the individual ad as the unit of analysis. There were no main or interactive effects of attention value or congruency, indicating no statistical variation in informational content between ads across treatment groups.

Test ads were created by voicing copy over music. Copy and music were matched/mismatched to operational- 
MUSIC-MESSAGE CONGRUENCY

\begin{tabular}{|c|c|c|}
\hline & LOW & $\mathrm{HIGH}$ \\
\hline $\begin{array}{l}\text { High } \\
\text { ATTENTION } \\
\text { GAINING }\end{array}$ & $\begin{array}{r}\cdot 4, \mathrm{H} \\
\cdot \quad 8, \mathrm{H} \\
\cdot 12, \mathrm{C} \\
\cdot 1, \mathrm{E} \\
\cdot 5, \mathrm{G} \\
\cdot 9, \mathrm{~B}\end{array}$ & $\begin{array}{l}\cdot 4, \mathrm{D} \\
\cdot \quad 8, \mathrm{E} \\
\cdot 12, \mathrm{I} \\
\cdot 1, \mathrm{~A} \\
\cdot \quad 5, \mathrm{E} \\
\cdot 9, \mathrm{~F}\end{array}$ \\
\hline $\begin{array}{l}\text { MUSIC } \\
\text { Low }\end{array}$ & $\begin{array}{r}\cdot 2, \mathrm{~A} \\
\cdot 10, \mathrm{~A} \\
\cdot 10, \mathrm{~F} \\
\cdot 3, \mathrm{D} \\
\cdot 7, \mathrm{D} \\
\cdot 11, \mathrm{I}\end{array}$ & $\begin{array}{r}\cdot 2, \mathrm{~B} \\
\cdot 6, \mathrm{E} \\
\cdot 10, \mathrm{G} \\
\cdot 3, \mathrm{C} \\
\cdot 7, \mathrm{E} \\
\cdot 11, \mathrm{H}\end{array}$ \\
\hline
\end{tabular}

\section{Key to Stimulus Combinations:}

\section{Musical Selections}

1. Concerto for Clarinet and Orchestra by Corigliano

2. "Moonlight-The Nymph's Rondele" from The Moldau (by Smetana)

3. "Shaker Loops" by Adams

4. "Les Preludes" by Liszt

5. "Nicaz Dolap" from Songs and Dances of Turkey

6. "To Minore tis Avgis" from Syrtos

7. "Taksim" from Songs and Dances of Turkey

8. "Karsilama" from Syrtos

9. "Triumph"-Lui Man-Sing (traditional Chinese)

10. "Reflections"-Winston (new age)

11. "Saturn"-Holst (classical)

12. "Real Love"-Cymone (instrumental pop)

\section{Ad Copy}

A. Adventure Movie

B. State Parks (PSA)

C. Acetaminophen Pain Reliever

D. Polo Club (restaurant)

E. Ethnos Restaurant

F. Ching Dynasty (restaurant)

G. Sonoma Wine Bar

H. Drugs (PSA)

I. Nightspot (singles bar) ize high/low congruency. Executional attributes such as duration, announcer's voice, recording quality, and loudness were held constant.

The final phase of pretesting involved a manipulation check on music-message congruency using two groups of college students $(n=60)$. A multi-item measure was used to represent music-message congruency (see "Measures"). ANOVA confirmed the congruency manipulation $\left(\overline{\mathrm{X}}_{\mathrm{H} / \mathrm{LO}}=\right.$ $4.01 / 1.95, F(1,22)=75.12, p<.001)$, and reconfirmed the attention-gaining manipulation $\left(\overline{\mathrm{X}}_{\mathrm{H} / \mathrm{LO}}=3.73 / 2.31, \mathrm{~F}(1,22)\right.$ $=41.13, p<.001$ ).

This multi-phase process resulted in a set of test ads that varied orthogonally in terms of music's attentiongaining value and music-message congruency. Each cell in this $2 \times 2$ experimental design was operationalized by six test ads. Multiple operations were used to increase the construct validity of the manipulations (Cook and Campbell
1979, p. 65). The specific product-music combinations for each ad are shown in Figure 1.

The test ads as well as dummy ads were embedded in a five-minute excerpt from a radio broadcast, which was taken from a radio documentary on human relationships that aired locally in another state. A humorous decaffeinated coffee commercial, which was heard twice, was the dummy.

\section{Procedure}

Subjects were processed individually in a listening lab. Each subject was given a set of headphones, a randomly assigned numbered cassette tape, and a (matching) numbered questionnaire, and then directed to an audio carrel. Printed instructions told subjects to rewind the tape, listen to it once, break the seal on the questionnaire, and complete the questionnaire. Unobtrusive observation of a subset of sub- 
jects found no violations of the instructions. The last page of the questionnaire directed subjects to return all materials to the lab attendant. Median processing time was $\mathbf{3 0}$ minutes.

Subjects were given a disguised cover story. The purpose of the study was described as "to assess the viability of a new media format for the college market." The questionnaire contained dummy items designed to support the cover story and create a time delay. These included questions on radio listening habits and the broadcast. Following the procedure used in Madden, Allen, and Twible's 1988 study, the questionnaire stated that "since your evaluations of the program might be influenced by the other things you heard, some people have been randomly selected to answer more detailed questions about other aspects of the broadcast. You have been assigned questions about. . . "' This was followed by six categories (e.g., "the sound quality"). A checkmark was placed next to "the advertisements" category on all copies of the questionnaire.

Subjects were asked to recall that one of the ads (dummy) was heard twice, at the beginning and end of the broadcast, and the other ad (target) was heard only once. Attention was drawn to the target ad by stating "the following questions concern the ad you heard only once."

\section{Measures}

Dependent measures. Open-ended items measured unaided brand name and message recall. The brand recall items asked "What was this ad for? Was there a specific brand mentioned? If so, what was it?' Message recall was prompted by the questions "What major points did the message make? Please list as many as you can remember. What other details do you remember from the ad?' These measures are patterned after those used in previous ad recall studies (e.g., Sewall and Sarel 1986; Singh, Rothschild, and Churchill 1988).

Brand name recall was coded dichotomously as accurate (including phonetically close spellings) or inaccurate recollection. Message recall was scored by isolating written protocols into individual phrases, as per Bettman and Park's 1980 study, and comparing them against the original ad copy. Exact matches and conceptually similar phrases were scored as correct, which served as an index of unaided message recall.

Coding of brand and message recall was done by one of the authors, who was blind to treatment group membership during coding. To check the coding judgments, a graduate assistant naive to the hypotheses recoded 100 of the cases using the same a priori criteria. A comparison of the two sets of coding judgments found significant positive correlations between brand $(\mathrm{r}=.73, p<.001)$ and message $(\mathrm{r}=$ $.87, p<.001)$ recall judgments.

Brand and message recognition were measured by checklists, as per Singh, Rothschild, and Churchill's 1988 study. Both checklists contained filler items designed to increase the sensitivity of the measure (Singh, Rothschild, and Churchill 1988). The brand name was embedded in an 18item checklist and the central message theme in a 20 -item checklist including "none of the above" and "I can't recall."

Manipulation and confounding checks. Single-item, 5point agreement scales were used for manipulation checks on music's attention-gaining value and for confounding checks on music appealingness, familiarity, and message relevance. It should be noted that we used a rating scale measure of attention-gaining value because we know of no direct (or observational) measures of auditory attention. Our stimuli are purely auditory and were heard over headphones. Given the unavailability of observational measures, we used stimuli with properties that are known antecedents to attention, employed rating scale measures of attentiongaining value, and measured predicted outcomes of attention-gaining value (i.e., recall and recognition).

A summed six-item, 5-point agreement scale was included to verify the manipulation of music-message congruency. Specific items include "Regardless of how much I liked or disliked the music, it did seem appropriate for this ad," "The music did not seem to fit the message in this ad" (*), "The message and music both made me think about the same things," "The music was not what I would expect to hear in this kind of ad" $\left({ }^{*}\right)$, "The music and the message both seemed to evoke the same general mood," and "The music and message seemed to be well matched in this ad." Items marked (*) were reverse-scored. Reliability of the composite congruency scale was .92 (Cronbach's alpha).

Other questionnaire items. Though our study focuses on cognitive responses to ads, we took measures of attitudes toward the ad $\left(A_{a d}\right)$ and brand $\left(A_{b}\right)$ to make sure our manipulations did not create unanticipated attitudinal effects. $A_{a d}$ and $A_{b}$ were measured after the recall and recognition items. A was measured using a five-item, 7-point semantic differential scale taken from MacKenzie, Lutz, and Belch's 1986 study. The items “"pleasant/unpleasant, likable/unlikable, interesting/uninteresting, tasteful/tasteless, and good/ bad" were preceded by the prompt "The ad I heard was...." Alpha reliability for the summed scale was .88. $\mathrm{A}_{\mathrm{b}}$ was measured using the same five items, but with a different prompt ("The product or service in the ad was..."). Alpha reliability for the summed $A_{b}$ scale was .91 .

The questionnaire included several debriefing items designed to assess the extent of hypothesis guessing and compliance with instructions. No subjects correctly guessed the hypotheses, and no consequential violations of the instructions were observed. Demographic items and questions concerning musical interests, listening habits, and training were included.

\section{Results}

\section{Posttest Manipulation and Confounding Checks}

Manipulation checks conducted at the end of the experiment ${ }^{1}$ confirmed that the high and low congruency treat-

\footnotetext{
${ }^{1}$ Perdue and Summers $(1986$, p. 320$)$ note that pretest manipulation checks (such as those reported previously) are the best gauges of manipulation strength, because by the time post-experimental checks are taken, the "effects of the manipulation may have already dissipated substantially." Consistent with this, we found that the "spread" between manipulation check means taken after our experiment were somewhat smaller than those in our pretests: 2.4 and 3.1 for low and high attention-value treatments $(F(1,159)=10.68, p<.001), 3.3$ and 3.8 for low and high congruency treatments $(\mathrm{F}(1,159)=10.08, p<.002)$. Still, both pre- and posttest measures indicate successful, unconfounded manipulations of the constructs of interest.
} 
ments differed significantly in perceived music congruency $(\mathrm{F}(1,159)=10.08, p<.002)$, but did not differ in perceived music attention value $(F=3.1)$, appeal $(F=.18)$, familiarity $(F=2.2)$, or personal relevancy $(F=.30)$. Similarly, the high and low attention-value treatments differed significantly in perceived attention value $(\mathrm{F}(1,159)=10.68, p<$ $.001)$ but not in perceived music congruency $(F=.26)$, appeal $(F=.02)$, familiarity $(F=.89)$, or personal relevancy $(F=3.5)$. Consistent with our expectations, the treatments did not produce significant main or interactive effects on attitudes toward the ad $\left(A_{a d}\right)$ or brand $\left(A_{b}\right)$. Therefore, the experimental manipulations appear to be both successful and unconfounded.

\section{MANOVA}

Because the four outcome variables are conceptually related as measures of ad reception/processing, we expected them to be statistically intercorrelated. Cross-tabulations of recall and recognition scores found four of the six pairs of dependent variables to be significantly and positively associated (at $p<.05$ ). The association of message recall with message recognition was positive, but not significant $(p=.11)$, and the association of brand recall with message recognition was not statistically significant.

Because intercorrelated variables were to be analyzed, we performed a multivariate variance analysis (MANOVA) to avoid Type I error inflation. MANOVA adjusts for the intercorrelation among dependent variables when calculating significance levels (Hair, Anderson, and Tatham 1987). The results are summarized in Table 1.

As anticipated in our hypotheses, music's attentiongaining value interacted with music-message congruency to produce a significant effect on cognitive measures of ad performance (Wilk's lambda $=.93369, \mathrm{~F}(4,161)=2.86, p<$ $.025)$. Neither experimental factor produced a significant main effect.

\section{ANOVA}

Given the positive MANOVA finding for the interaction, follow-up univariate analyses were performed on each ad performance measure (Hair et al. 1987). Though some of our dependent measures were not normally distributed, our data contained no problematic violations of the underlying assumptions of analysis of variance (ANOVA). ${ }^{2}$ (It should be noted that the $\mathrm{F}$ test is robust to deviations from normal-

${ }^{2}$ Two methodological issues pertaining to this analysis merit comment: The first concerns the assumptions underlying the ANOVA model. As Lindman $(1974$, p. 21$)$ points out, "none of the assumptions [underlying ANOVA] are ever fully satisfied by data;' however, the F test is extremely robust. First, ANOVA assumes that the dependent variables are normally distributed. The only notable departure from normality in our data is nonzero kurtosis, particularly in the message recognition measure $(\mathrm{Ku}=$ -1.92). However, when these kurtoses were incorporated into Box and Anderson's (1955) approximate F test, results were identical to those of the conventional $F$ test. (For a discussion of the robustness of the $F$ test, see Lindman 1974, pp. 31-33.) Second, ANOVA assumes equal variances among experimental groups. Cochran's test for homogeneity of variance revealed no significant differences across cells for any of the four dependent measures. Third, ANOVA assumes independent observations. Because our subjects were randomly assigned to treatments and had no knowledge of one another's responses (because of individual processing), our data adhere to this assumption.

The second issue concerns the error terms used in the analyses of vari- ity, especially given relatively large sample sizes. See Lindman 1974.) ANOVA results are summarized in Table 1, and descriptive data appear in Table 2.

$H_{1}$ recall effects. $\mathrm{H}_{1 \mathrm{a}}$ concerning brand recall was supported. The interaction of music's attention-gaining value with music-message congruency, $\mathrm{F}(1,164)=3.94, p<.05$, is illustrated in Figure 2. The effect size $\left(\omega^{2}\right)$ for this interaction is .02 (Keppel 1982). Attention-gaining music has a positive effect on brand name recall $(t=-2.75$, d.f. $=82$, $p$ $<.01)$ under the high music-message congruency condition, and no effect under the low congruency condition. Brand recall differed between low $(\overline{\mathrm{X}}=.29)$ and high $(\overline{\mathrm{X}}=.55)$ congruency groups under the high attention-gaining condition $(\mathrm{t}=-2.49$, d.f. $=82, p<.015)$ but not under the low attention-gaining condition.

$\mathrm{H}_{1 b}$ concerning message recall was also supported. The interaction of attention value and congruency, $\mathrm{F}(1,164)=$ $4.64, p<.04, \omega^{2}=.02$, is illustrated in Figure 3. Music's attention-gaining value has a positive effect on message recall $(\overline{\mathrm{X}}=1.48$ vs. 2.40$)$ under the high music-message congruency condition $(\mathrm{t}=-2.66$, d.f. $=82, p<.01)$. The slight decrement in recall seen across attention value levels under the low congruency condition $(\overline{\mathrm{X}}=1.48$ vs. 1.38 ) is not significant $(t=.30)$. Though there is no recall difference between congruency groups under the low attention value condition, a significant difference $(\overline{\mathrm{X}}=1.38$ vs. 2.40$)$ emerges when attention value is high $(\mathrm{t}=-2.48$, d.f. $=82, p<.01)$.

$\mathrm{H}_{2}$ recognition effects. $\mathrm{H}_{2 \mathrm{a}}$ concerning brand recognition was not supported $\left(\mathrm{p}={ }^{2 \mathrm{a}} 12\right)$. The failure to find between-group differences in this measure may have been caused by the sensitivity of the measure. Brand recognition can be a relatively "easy" test of memory (Singh et al. 1988), especially after exposure to only a few ads and a relatively brief delay. Only $16.8 \%$ of our subjects failed to recognize the target brand on a checklist.

$\mathrm{H}_{2 \mathrm{~b}}$ concerning message recognition was supported. A significant interaction of music's attention-gaining value with music-message congruency was found, $F(1,164)=$ $5.54, p<.02, \omega^{2}=.03$, as shown in Figure 4. There is a positive effect of attention-gaining music on message recognition under the high congruency condition $(\mathrm{t}=-1.78$, d.f. $=$ $82, p<.04)$, and no effect when congruency is low $(\mathrm{t}=$ 1.55 , n.s.). High $(\overline{\mathrm{X}}=.48)$ and low $(\overline{\mathrm{X}}=.67)$ congruency groups differ statistically in terms of message recognition under the low attention-gaining music condition $(t=1.78$,

ance. The error terms in the reported ANOVAs represent the variance across subjects within cells of the experiment. Technically this involves pooling two sources of variance: variance across stimuli within a cell and across subjects exposed to a given stimulus. To examine the appropriateness of this pooling of variance, we conducted the "pooling test" suggested by Keppel (1982, p. 264). This test revealed that there were statistically significant differences across stimuli within cells, for both brand and message recognition (but not for brand or message recall). Hence, we followed Keppel's suggestion and reanalyzed the interactive effect of congruency and attention value on these two recognition variables, using the within-cell variance across stimuli (d.f. $=24-4=20$ ) as the error term. When this was completed, the $\mathrm{F}$ test was statistically significant for message recognition $(F(1,20)=8.4, p<.01)$ and not significant for brand recognition $(F(1,20)=1.1, p .3)$. This is essentially the same result that occured in the original "pooled"' analysis. Because the results are the same and the original pooled analysis is more widely understood and simpler to present, it is reported for all four dependent variables. 
TABLE 1

Overview of Variance Analyses

\begin{tabular}{|c|c|c|c|c|c|c|c|c|}
\hline \multirow[b]{2}{*}{$\begin{array}{l}\text { Independent } \\
\text { Variable }\end{array}$} & \multirow[b]{2}{*}{$\begin{array}{l}\text { Dependent } \\
\text { Variable }\end{array}$} & \multicolumn{4}{|c|}{ MANOVA Results } & \multicolumn{3}{|c|}{ ANOVA Results } \\
\hline & & Wilk's lambda & $\mathbf{F}$ & d.f. & $p<$ & $\mathbf{F}$ & d.f. & $p<$ \\
\hline $\begin{array}{l}\text { Attention- } \\
\text { Gaining } \\
\text { Value of } \\
\text { Music }\end{array}$ & $\begin{array}{l}\text { Brand recall } \\
\text { Message recall } \\
\text { Brand recognition } \\
\text { Message recognition }\end{array}$ & .95799 & 1.76 & $(4,161)$ & n.s. & $\begin{array}{r}3.94 \\
3.07 \\
3.92 \\
<1\end{array}$ & $\begin{array}{l}1,164 \\
1,164 \\
1,164 \\
1,164\end{array}$ & $\begin{array}{l}\text { n.s. } \\
\text { n.s. } \\
.05 \\
\text { n.s. }\end{array}$ \\
\hline $\begin{array}{l}\text { Music- } \\
\text { Message } \\
\text { Congruency } \\
\text { (MMC) }\end{array}$ & $\begin{array}{l}\text { Brand recall } \\
\text { Message recall } \\
\text { Brand recognition } \\
\text { Message recognition }\end{array}$ & .96707 & 1.37 & $(4,161)$ & n.s. & $\begin{array}{l}2.73 \\
4.64 \\
<1 \\
<1\end{array}$ & $\begin{array}{l}1,164 \\
1,164 \\
1,164 \\
1,164\end{array}$ & $\begin{array}{l}\text { n.s. } \\
.033 \\
\text { n.s. } \\
\text { n.s. }\end{array}$ \\
\hline $\begin{array}{l}\text { Attention } \\
\text { by MMC } \\
\text { Interaction }\end{array}$ & $\begin{array}{l}\text { Brand recall } \\
\text { Message recall } \\
\text { Brand recognition } \\
\text { Message recognition }\end{array}$ & .93369 & 2.85 & $(4,161)$ & .025 & $\begin{array}{l}3.94 \\
4.64 \\
2.51 \\
5.54\end{array}$ & $\begin{array}{l}1,164 \\
1,164 \\
1,164 \\
1,164\end{array}$ & $\begin{array}{c}.05 \\
.033 \\
\text { n.s. } \\
.02\end{array}$ \\
\hline
\end{tabular}

TABLE 2

Cell Means and Standard Deviations for Experiment ${ }^{1}$

\begin{tabular}{|c|c|c|c|c|c|c|}
\hline \multirow[b]{3}{*}{$\begin{array}{l}\text { Dependent } \\
\text { Variable }\end{array}$} & \multicolumn{4}{|c|}{ Attention-Gaining Value } & \multirow[b]{3}{*}{$\begin{array}{c}\begin{array}{c}\text { Total } \\
(\mathrm{N}=168)\end{array}\end{array}$} & \multirow[b]{3}{*}{$\begin{array}{l}\text { Contro } \\
\text { Group } \\
(n=64)\end{array}$} \\
\hline & \multicolumn{2}{|c|}{ Low } & \multicolumn{2}{|c|}{ High } & & \\
\hline & $\begin{array}{c}\text { Low } \\
\text { Congruency } \\
(n=42)\end{array}$ & $\begin{array}{c}\begin{array}{c}\text { High } \\
\text { Congruency } \\
(n=42)\end{array} \\
\text {. }\end{array}$ & $\begin{array}{c}\text { Low } \\
\text { Congruency } \\
(\mathrm{n}=42)\end{array}$ & $\begin{array}{c}\begin{array}{c}\text { High } \\
\text { Congruency } \\
(n=42)\end{array} \\
\end{array}$ & & \\
\hline Brand Recall & $\begin{array}{c}.286 \\
(.457)\end{array}$ & $\begin{array}{c}.262 \\
(.445)\end{array}$ & $\begin{array}{c}.286 \\
(.457)\end{array}$ & $\begin{array}{c}.548 \\
(.504)\end{array}$ & $\begin{array}{c}.345 \\
(.477)\end{array}$ & $\begin{array}{c}.516 \\
(.504)\end{array}$ \\
\hline Message Recall & $\begin{array}{c}1.476 \\
(1.518)\end{array}$ & $\begin{array}{c}1.476 \\
(1.311)\end{array}$ & $\begin{array}{c}1.381 \\
(1.431)\end{array}$ & $\begin{array}{c}2.405 \\
(1.849)\end{array}$ & $\begin{array}{c}1.685 \\
(1.583)\end{array}$ & $\begin{array}{c}1.953 \\
(1.786)\end{array}$ \\
\hline Brand Recognition & $\begin{array}{c}.786 \\
(.415)\end{array}$ & $\begin{array}{c}.714 \\
(.457)\end{array}$ & $\begin{array}{c}.810 \\
(.397)\end{array}$ & $\begin{array}{c}.929 \\
(.261)\end{array}$ & $\begin{array}{c}.810 \\
(.394)\end{array}$ & $\begin{array}{c}.891 \\
(.315)\end{array}$ \\
\hline Message Recognition & $\begin{array}{c}.667 \\
(.477) \\
\end{array}$ & $\begin{array}{c}.476 \\
(.505) \\
\end{array}$ & $\begin{array}{c}.500 \\
(.506) \\
\end{array}$ & $\begin{array}{c}.667 \\
(.477) \\
\end{array}$ & $\begin{array}{c}.577 \\
(.495) \\
\end{array}$ & $\begin{array}{c}.734 \\
(.445) \\
\end{array}$ \\
\hline
\end{tabular}

${ }^{1}$ Table entries are means (standard deviations).

d.f. $=82, p<.04)$, but not under the high attention-gaining condition $(t=-1.55$, n.s.).

\section{Comparisons with Nonmusical Control Ads}

The inclusion of no-music control groups in our design allows us to compare the performance of musical ads with nonmusical versions of the same ads. Though we had no $a$ priori hypotheses concerning the relative performance of musical versus nonmusical ads, we examined this issue in a series of exploratory analyses. Control group means appear as horizonal dash lines on Figures 2, 3, and 4.

The nonmusical "control" versions of the test ads performed significantly better on brand recall $\left(\overline{\mathrm{X}}_{\text {control }}=.51\right.$, minimum $t$ for contrasts $=2.38$, d.f. $=104, p<.02$ ) than all the musical ads except the high-attention value/ high-congruency ads $(\overline{\mathrm{X}}=.55)$. The nonmusical control ads scored equally as well as the "high-high" ads $(t=-.32$, n.s.) on brand recall. There were no statistical differences between the nonmusical ads and the treatment ads in terms of message recall ( $t$ 's for all contrasts n.s.).
Though there were no statistical effects of musical treatments on brand recognition, the nonmusical control ads ( $\overline{\mathrm{X}}$ $=.89$ ) actually performed better than the low-attention value/high-congruency musical ads $(\bar{X}=.71 ; t=2.35$, d.f. $=104, p<.02)$ on this measure. On the message recognition measure, the nonmusical control ads $(\overline{\mathrm{X}}=.73)$ performed better than both the low-attention value/high-congruency $(\overline{\mathrm{X}}=.48, \mathrm{t}=2.77$, d.f. $=104, p<.007)$ and highattention value/low-congruency ads $(\overline{\mathrm{X}}=.50, \mathrm{t}=2.51$, d.f. $=104, p<.014)$.

\section{Discussion and Conclusion}

We examined the proposition that ad recall and recognition are enhanced by attention-gaining background music that communicates message-congruent meanings (relative to attention-gaining music that communicates message-incongruent meanings). This proposition received fairly consistent, but not uniform, empirical support. The interaction between music-message congruency and music's attention-gaining value was of the predicted shape and statistically significant 


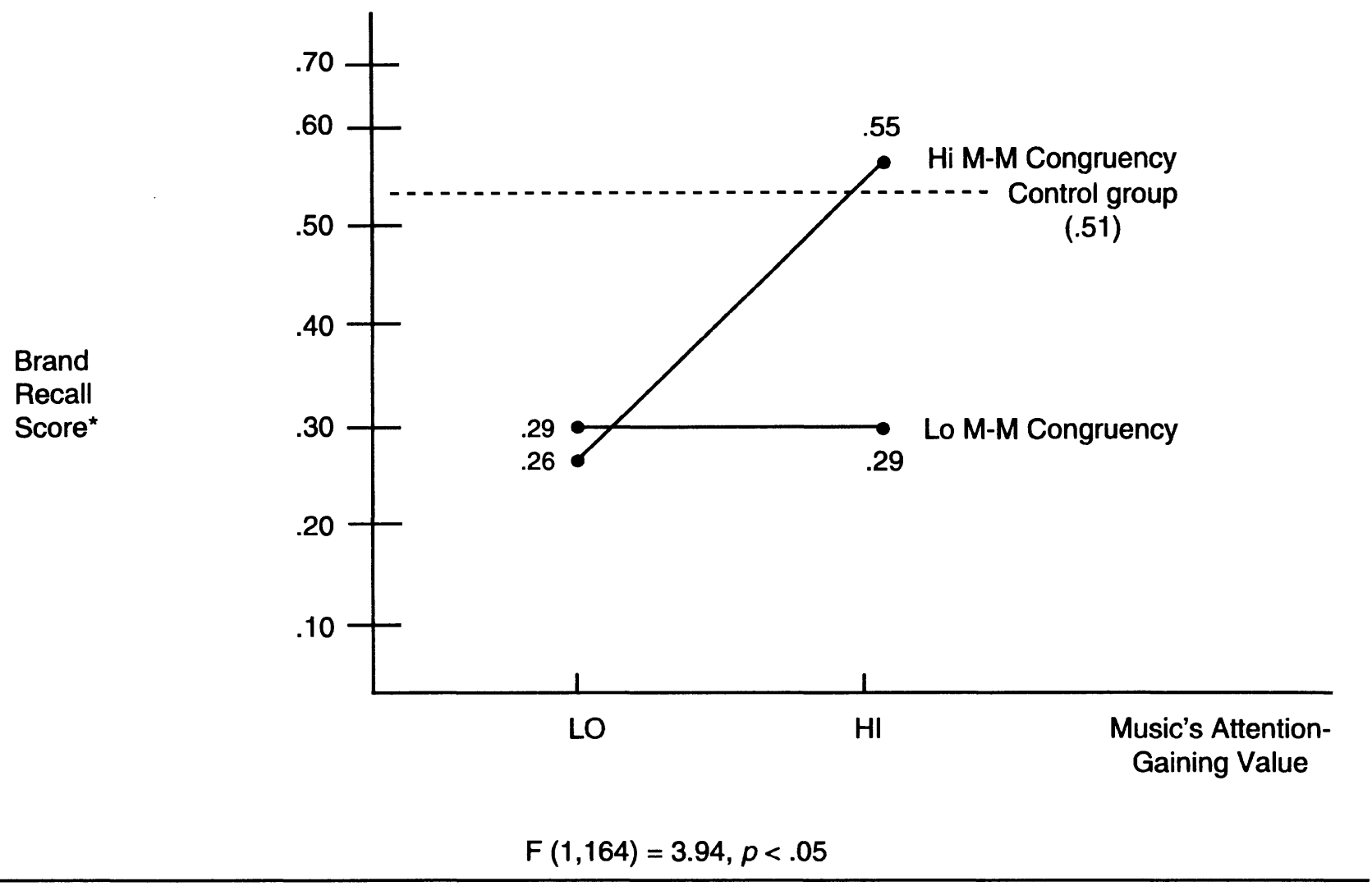

*Each cell mean represents the aggregation of six test ads.

$(p<.025)$ in the MANOVA on all four memorability measures, as well as the individual variance analyses (ANOVAs) for brand recall, message recall, and message recognition. Though a plot of the results for brand recognition appeared to follow the same pattern, this interaction was not statistically significant. This result might be explained partially by the relative difficulty of the processing tasks demanded by different measures of ad memorability. Brand name recognition is probably the easiest task among memorability measures (see Singh, Rothschild, and Campbell 1988). Most of our subjects (more than $83 \%$ ), regardless of treatment group, had no trouble recognizing the advertised brand. As a result, there was little variation in this measure.

Still, our study suggests that music-message congruency can moderate the influence of music's attention-gaining value on at least some aspects of ad recall and recognition. When congruency is high, attention-gaining music seems to contribute positively to these outcomes. When congruency is low, attention-gaining music seems to serve more as a distraction from ad processing. This interactive phenomenon may help explain some of the conflicting findings reported in previous research on the relationship between background music and ad effectiveness. Perhaps studies reporting positive effects of music on message reception employed music of higher congruency and attention value than those reporting negative effects. This would parsimoni- ously explain why music sometimes facilitates and sometimes interferes with message reception.

Our study has some interesting parallels to an earlier psychological study by Hastie and Kumar (1979) concerning stimulus congruity. Their study presented information that varied in internal consistency. Recall was found to be higher for moderately incongruous information. On the surface, our findings seem to contradict this earlier finding; however, the apparent contradiction can be explained in terms of differences in stimuli and exposure conditions. Hastie and Kumar's subjects were allowed to scrutinize elements of information presented sequentially, whereas our subjects had to sort out two auditory signals (background music and spoken message) that were simultaneously vying for their attention. Therefore, we predict (and our data seem to confirm) that when background music is both attentiongaining and message-incongruent, it will pull listeners' attention away from the message, thereby harming recall. Boltz, Schulkind, and Kantra (1991) found that the effect of "'mood incongruent" music on recall of filmed events depended on whether the music was presented concurrently or sequentially with the scene's outcome. Future research could investigate the effect of presenting a message and incongruent/ high attention value music sequentially in ads.

Our primary focus here is on comparing the effects of different types of background music. However, one of the most striking findings is that the no-music ads performed 


\section{Message \\ Recall \\ Score}

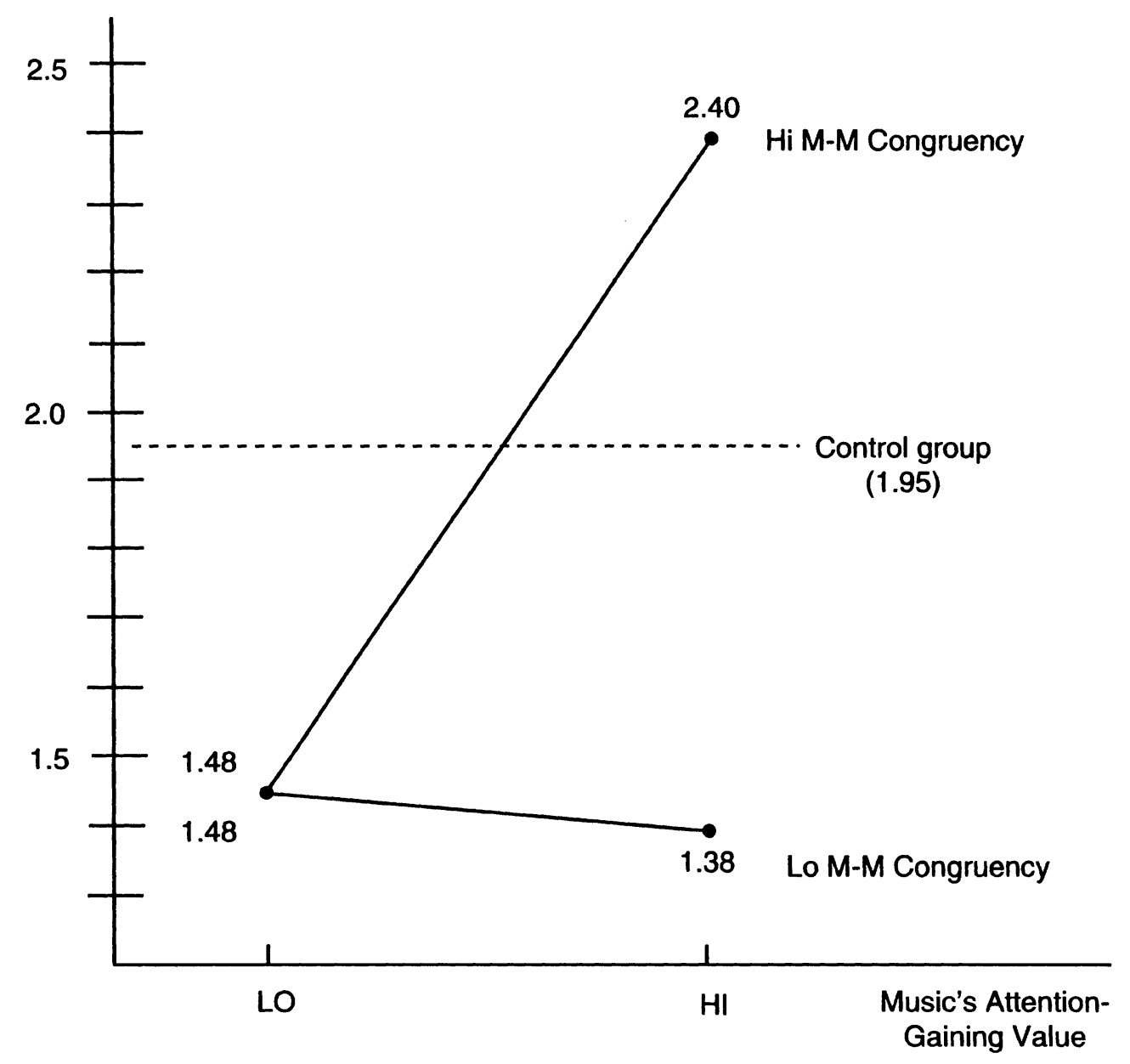

$F(1,164)=4.64, p<.033$

about as well as (and in some cases better than) the musical ads in terms of recall and recognition. As discussed previously, music is used almost universally in broadcast ads, partially because of the widely held belief that it is an effective aid to recall (Hecker 1984). Lipman (1991) recently argued that this practice reflects the "bandwagon" mentality of some advertisers and agencies and that music may actually interfere with message reception. The findings of this study offer some support for these concerns. It is premature, however, to conclude that background music should be excluded from broadcast ads. Even music that interferes with message recall and other cognitive processes could enhance ad effectiveness through an emotional route, such as mood elevation (Gardner 1985) and affect transfer (Lutz 1985). In addition, music's distracting effects may have benefits over repeated exposures (Anand and Sternthal 1990).

The present study has several limitations that should be addressed in further research. First, our stimulus music was purely instrumental and generally unfamiliar to listeners.
The moderating effect of music-message congruency should be tested with other types of music, including vocals and well-known songs, to assess generality. Second, our hypotheses were tested in a radio advertising context. The generality of the findings to TV advertising should be explored further. Third, our sample was limited to one population group-college students. Though this group was an appropriate target audience for each test ad, their membership in the "MTV generation" may affect the way they respond to both auditory and visual elements of broadcast ads. Fourth, though our measures of memorability are consistent with those used in past academic research (e.g., Sewall and Sarel 1986; Singh, Rothschild, and Churchill 1988), they differ somewhat from those typically used in commercial copy testing, both in terms of how the questions were phrased and the time lag between exposure and testing. Additional research should examine whether music has varying effects on alternative measures of ad recall, and particularly whether delaying measurement (e.g., day-after recall) dimin- 


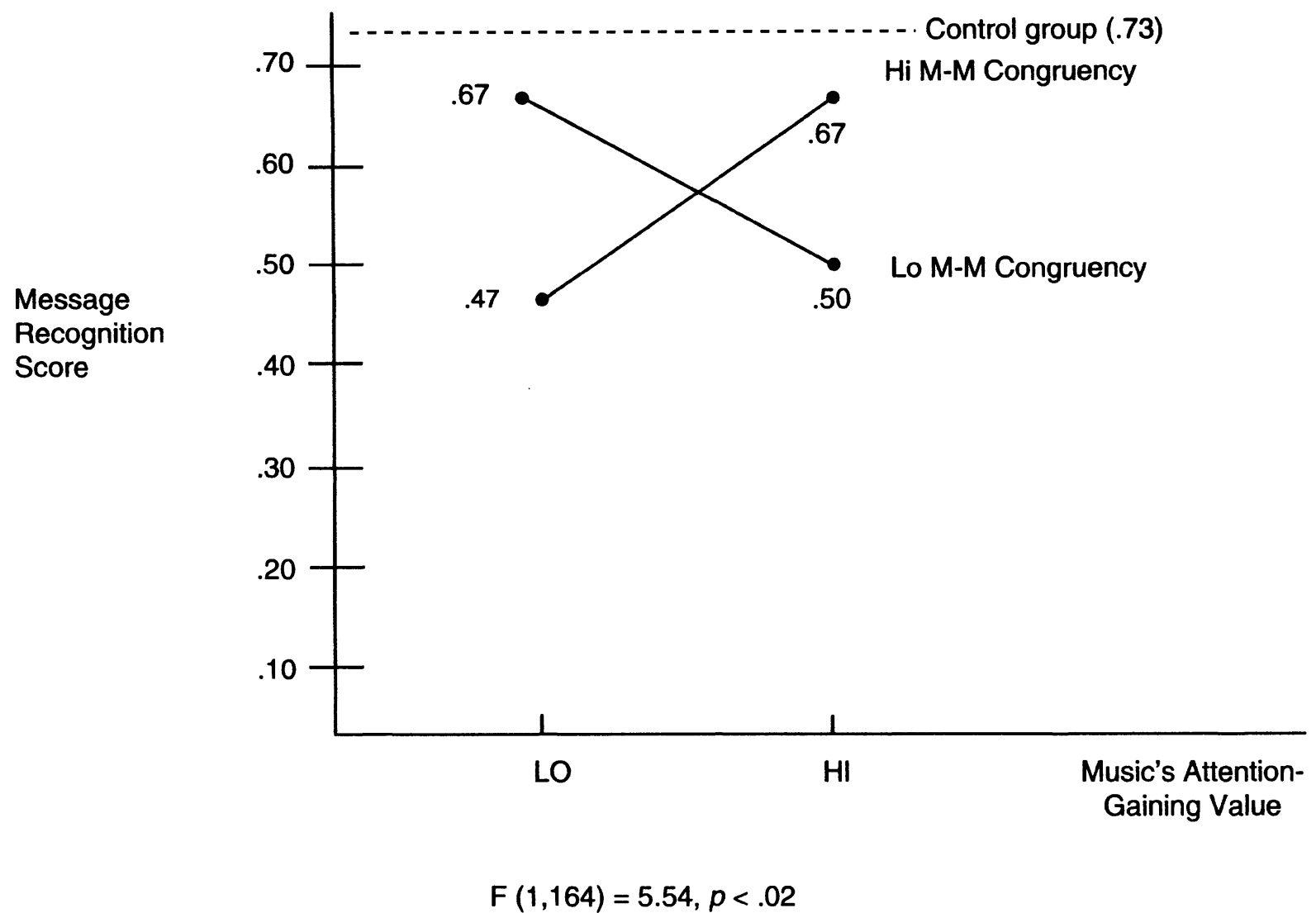

ishes or augments the effects observed in this study. Finally, further research should introduce additional elements of real-world ad exposure, such as environmental distraction and repetition, to see if and how they might alter the effects observed in this study.

With these limitations in mind, we suggest two tentative implications of our findings for the use of music in advertising. First, the findings suggest that advertisers should consider the use of music in relation to their communication goals. In cases in which brand awareness and knowledge are primary objectives, the design or selection of music should be approached with extreme caution to avoid music that may inhibit consumers' reception of message and brand name. Second, if an advertiser uses music, it should be pretested for its ability to generate attention and for congruency of music- and message-generated thoughts, images, and feelings. Tentatively, our results would seem to suggest the selection of highly attention-gaining, highly congruent music over other categories of music.

In general, this study supports Bruner's (1990) contention that music, rather than being a homogeneous "sonic mass," is a complex, multidimensional stimulus that can affect marketing outcomes in various and sometimes surprising ways. This is an important area for continued research.

\section{REFERENCES}

Aaron, Charles (1987), "Music in Advertising," Adweek (September 14), F.P. 21.

Alpert, Judy I. and Mark I. Alpert (1990), "Music Influences on Mood and Purchase Intentions," Psychology and Marketing, 7 (2), 109-33.

Alsop, Ronald (1985), “Ad Agencies Jazz Up Jingles by Playing on 1960's Nostalgia," Wall Street Journal (April 18), B1.

Anand, Punam and Brian Sternthal (1990), "Ease of Message Processing as a Moderator of Repetition Effects in Advertising," Journal of Marketing Research, 27 (August), 345-53.

Belsham, Richard Lee and David W. Harman (1977), "Effect of Vocal vs. Nonvocal Music on Visual Recall," Perceptual and
Motor Skills, 44, 857-8.

Berlyne, D. E. (1974), Studies in the New Experimental Aesthetics. Washington, DC: Hemisphere Publishing.

Bettman, James R. and C. Whan Park (1980), "Effects of Prior Knowledge and Experience and Phase of the Choice Process on Consumer Decision Processes: A Protocol Analysis," Journal of Consumer Research, 7 (December), 234-48.

$\rightarrow$ Boltz, Marilyn, Matthew Schulkind, and Suzanne Kantra (1991), "Effects of Background Music on the Remembering of Filmed Events," Memory and Cognition, 19 (6), 593-606.

Box, G. E. P. and S. L. Anderson (1955), "Permutation Theory in the Derivation of Robust Criteria and the Study of Departure 
from Assumptions," Journal of the Royal Statistical Society, Series $\mathrm{B}, 17,1-34$.

Bruner, Gordon C., II (1990), “Music, Mood, and Marketing," Journal of Marketing, 54 (October), 94-104.

Childers, Terry L. and Michael J. Houston (1984), "Conditions for a Picture-Superiority Effect on Consumer Memory,' Journal of Consumer Research, 11 (September), 643-54.

$\rightarrow$ Cocks, Jay (1987), “Wanna Buy a Revolution?” Time (May 18), 78.

Cook, Thomas and Donald Campbell (1979), Quasi-Experimentation: Design and Analysis Issues for Field Settings. Chicago: Rand McNally.

Enrico, Roger and Jesse Kornbluth (1986), The Other Guy Blinked-How Pepsi Won the Cola Wars. New York: Bantam Books.

Galizio, Mark and Clyde Hendrick (1972), "Effect of Musical Accompaniment on Attitude: The Guitar as a Prop for Persuasion," Journal of Applied Psychology, 2 (4), 350-59.

Gardner, Meryl Paula (1985), "Mood States and Consumer Behavior: A Critical Review," Journal of Consumer Research, 12 (December), 281-300.

Garfield, Bob (1988), "Too Much Ad Music Leaves Little Room for Hitting the Right Note," Advertising Age (January 4), 46.

Gorn, Gerald J. (1982), "The Effects of Music in Advertising on Choice Behavior: A Classical Conditioning Approach,' Journal of Marketing, 46 (Winter), 94-101.

Gundlach, Ralph H. (1935), "Factors Determining the Characterization of Musical Phrases," American Journal of Psychology, 47 (October), 624-43.

Gurney, Edmund (1880), The Power of Sound. London: Smith, Elder, and Company.

Hair, Joseph F., Jr., Rolph E. Anderson, and Ronald L. Tatham (1987), Multivariate Data Analysis, 2nd ed. New York: Macmillan Publishing Company.

Haley, Russell I., Jack Richardson, and Beth M. Baldwin (1984), "The Effects of Nonverbal Communications in Television Advertising," Journal of Advertising Research, 24 (4), 11-18.

Hastie, Reid and Purohit Anand Kumar (1979), "Person Memory: Personality Traits as Organizing Principles in Memory for Behaviors," Journal of Personality and Social Psychology, 37 (1), 25-38.

Hecker, Sidney (1984), “Music for Advertising Effect," Psychology and Marketing, 1 (Fall/Winter), 3-8.

Heckler, Susan E. and Terry L. Childers (1992), "The Role of Expectancy and Relevancy in Memory for Verbal and Visual Information: What Is Incongruency?' Journal of Consumer Research, 18 (4), 475-92.

$\rightarrow$ Heeter, Carrie and Bradley S. Greenberg (1985), "Profiling the Zappers," Journal of Advertising Research, 25 (April/May), $15-19$

Hettinger, Herman S. (1933), A Decade of Radio Advertising. Chicago: University of Chicago Press.

Holbrook, Morris B. and Stephen A. Bertges (1981), "Perceptual Veridicality in Esthetic Communication," Communication Research, 8 (October), 387-424.

Houston, Michael J., Terry L. Childers, and Susan E. Heckler (1987), "Picture-Word Consistency and the Elaborative Processing of Advertisments," Journal of Marketing Research, 24 (November), 359-69.

Hoyer, Wayne D., R. K. Srivastava, and Jacob Jacoby (1984), "Sources of Miscomprehension in Television Advertising," Journal of Advertising, 13 (2), 17-26.

Karmen, Steve (1989), Through the Jingle Jungle. New York: Billboard Books.

Kellaris, James J. and Robert J. Kent (1991), " Exploring Tempo and Modality Effects on Consumer Responses to Music,' in Advances in Consumer Research, vol. 18, R. H. Holman and M. R. Solomon, eds. Provo, UT: Association for Consumer Re- search, 243-8.

Keppel, Geoffrey (1982), Design and Analysis: A Researcher's Handbook, 2nd ed. Englewood Cliffs, NJ: Prentice-Hall, Inc.

Kroeber-Riel, Werner (1979), "Activation Research: Psychobiological Approaches in Consumer Research," Journal of Consumer Research 5 (March), 240-50.

Krugman, Herbert E. (1988), "Limits to the Attention of Advertising," Journal of Advertising Research, 28 (5), 47-50.

Lindman, Harold R. (1974), Analysis of Variance in Complex Experimental Designs. San Francisco: W. H. Freeman \& Company.

Lipman, Joanne (1991), "MTV Style, the Rage of the '80s, Falls From Favor at Many Shops," Wall Street Journal (February 12), p. B6.

Lutz, Kathy A. and Richard J. Lutz (1977), "Effects of Interactive Imagery on Learning: Applications to Advertising," Journal of Applied Psychology, 62 (4), 493-98.

Lutz, Richard (1985), "Affective and Cognitive Antecedents of Attitude Toward the Ad: A Conceptual Framework,' in Psychological Processes and Advertising Effects, L. Alwitt and A. Mitchell, eds. Hillsdale, NJ: Erlbaum.

MacInnis, Deborah J. and C. Whan Park (1991), "The Differential Role of Characteristics of Music on High and Low Involvement Consumers' Processing of Ads," Journal of Consumer Research, 18 (September), 161-73.

MacKenzie, Scott B., Richard J. Lutz, and George E. Belch (1986), "The Role of Attitude Toward the Ad as a Mediator of Advertising Effectiveness: A Test of Competing Explanations," Journal of Marketing Research, 23 (May), 130-43.

Macklin, M. Carole (1988), "The Relationship Between Music in Advertising and Childrens' Responses: An Experimental Investigation," in Nonverbal Communication in Advertising, S. Hecker and D. W. Stewart, eds. Lexington, MA: D. C. Heath and Co., 225-52.

Madden, Thomas J., Chris T. Allen, and Jacquelyn L. Twible (1988), "Attitude Toward the Ad: An Assessment of Diverse Measurement Indices Under Different Processing 'Sets,' " Journal of Marketing Research, 25 (3), 242-52.

Meyer, Leonard B. (1956), Emotion and Meaning in Music. Chicago: University of Chicago Press.

Michlin, Spencer (1984), "When to Play It Again," Television Radio Age, July 23, 66.

MRI (1989), Multimedia Audiences Report, M3. New York: Mediamark Research, Inc. (Spring), 11.

Olney, Thomas J., Morris B. Holbrook and Rajeev Batra (1991), "Consumer Responses to Advertising: The Effects of Ad Content, Emotions, and Attitude Toward the Ad on Viewing Time," Journal of Consumer Research, 17 (March), 440-53.

Perdue, Barbara C., and John O. Summers (1986), "Checking the Success of Manipulations in Marketing Experiments," Journal of Marketing Research, 23 (November), 317-26.

Rigg, Melvin G. (1937), “An Experiment to Determine How Accurately College Students Can Interpret Intended Meanings of Musical Compositions,' Journal of Experimental Psychology, 21, 223-9.

Scott, Linda M. (1990), “Understanding Jingles and Needledrop: A Rhetorical Approach to Music in Advertising," Journal of Consumer Research, 17 (September), 223-36.

Sewall, Murphy A. and Dan Sarel (1986), "Characteristics of Radio Commercials and Their Recall Effectiveness," Journal of Marketing, 50 (January), 52-60.

Singh, Surendra N., Michael L. Rothschild and Gilbert A. Churchill, Jr. (1988), "'Recognition Versus Recall as Measures of Television Commercial Forgetting," Journal of Marketing Research, 25 (February), 72-80.

$\rightarrow$ Srull, Thomas K., Meryl Lichtenstein, and Myron Rothbart (1985), "Associative Storage and Retrieval Processes in Person Memory," Journal of Experimental Psychology: Learning, 
Memory, and Cognition, 11 (2), 316-45.

Stewart, David W. and David H. Furse (1986), Effective Television Advertising-A Study of 1000 Commercials. Lexington, MA: D.C. Heath and Co.

- and R. P. Kozak (1983), "A Guide to CopyTesting Services," Current Issues and Research in Advertising, 1, 1-44.

Tharp, Paul (1989), “'To Sing's the Thing, In Jingles,” New York Post (April 11).

Tom, Gail (1990), “Marketing with Music,' Journal of Consumer Marketing, 7 (Spring), 49-53.

Tovey, Donald Francis (1937), Essays in Musical Analysis. London: Oxford University Press.

Unnava, H. Rao and Robert E. Burnkrant (1991), “An ImageryProcessing View of the Role of Pictures in Print Advertisements," Journal of Marketing Research, 28 (2), 226-31.

Wakshlag, Jacob J., Raymond J. Reitz, and Dolf Zillman (1982), "Selective Exposure and Acquisition of Information from Educational Television Programs as a Function of Appeal and
Tempo of Background Music," Journal of Educational Psychology, 74 (5), 666-77.

Walker, David and Michael F. von Gonten (1989), “Explaining Related Recall Outcomes: New Answers From A Better Model,' Journal of Advertising Research, 29 (June/July), 11-21.

Wallace, Wanda T. (1991), “Jingles in Advertisements: Can They Improve Recall?' in Advances in Consumer Research, vol. 18, R. H. Holman and M. R. Solomon, eds. Provo, UT: Association for Consumer Research, 239-42.

Watson, K. Brantley (1942), "The Nature and Measurement of Musical Meanings," Psychological Monographs, 54 (2), 1-48.

Webb, Peter H. and Michael L. Ray (1979), "Effects of TV Clutter," Journal of Advertising Research, 19 (June), 7-12.

Wells, William D. (1964), "Recognition, Recall and Rating Scales," Journal of Advertising Research, 4 (3), 2-8.

Yorke, David A. and Philip J. Kitchen (1985), "Channel Flickers and Video Speeders," Journal of Advertising Research, 25 (April/May), 21-25.

\section{AMERICAN MARKETING ASSOCIATION REPRINT AND PERMISSION POLICIES AND PROCEDURES FOR JOURNAL ARTICLES}

The American Marketing Association is eager to serve you in the sharing of the valuable information found in AMA's journal articles.

\section{REPRINTS}

If you wish to order REPRINTS of any article, write to the American Marketing Association Publications Group, 250 S. Wacker Dr., Chicago, IL 60606 USA. Call (312) 993-9517 or Fax (312) 993-7540.

The prices below apply to each title ordered. Multiple titles may be combined to reach the minimum order amount of $\$ 15$. Each reproduction will be provided with an attached cover. ORDERS INCLUDING SHIPPING AND HANDLING CHARGES MUST BE PREPAID by check (in U.S. funds or equivalent) or major credit card (VISA, American Express, MasterCard). No refunds or exchanges.

\begin{tabular}{|c|c|c|c|c|c|c|c|c|c|}
\hline $1-5^{*}$ & $\begin{array}{l}\text { reproductions of the same article } \\
\text { or an assortment of articles }\end{array}$ & $\$ 7.5$ & each & + & $\$ 6$ & $\begin{array}{l}\text { for U.S. Shipping } \\
\text { \& Handling }\end{array}$ & or & $\$ 9$ & $\begin{array}{l}\text { for International } \\
\text { Air S \& H }\end{array}$ \\
\hline $6-14^{*}$ & $"$ & $\$ 6$ & $"$ & + & $\$ 9$ & $"$ & or & $\$ 14$ & $"$ \\
\hline $15-49$ & reproductions of the same article & $\$ 5$ & $"$ & + & $\$ 12$ & $"$ & or & $\$ 21$ & $"$ \\
\hline $50-149$ & $"$ & $\$ 3$ & $"$ & + & $\$ 19$ & $"$ & or & $\$ 42$ & $"$ \\
\hline $150-500$ & $"$ & $\$ 2$ & $"$ & + & $\$ 34$ & $"$ & or & $\$ 87$ & $"$ \\
\hline$>500$ & $"$ & call & quote & & & & & & \\
\hline
\end{tabular}

An order of less than 50 copies also may be obtained from University Microfilms International, 300 N. Zeeb Road, Ann Arbor, MI 48106 . Articles are priced prepaid at $\$ 10.75$ plus $\$ 2.25$ for each additional copy of the same article. Those who have a standing account with UMI pay $\$ 8.75$ per article plus $\$ 2.25$ for each additional copy of the same article.

\section{PERMISSIONS}

AMA would be proud to grant permission for the reproduction of its copyrighted materials. To obtain permission to reproduce multiple copies, contact the AMA Publications Group (312) 831-2751. Under the "fair use" provision of the U.S. Copyright Law, anyone may make a photocopy for his or her own use without seeking permission. 